\section{PP3-053 膀胱鏡検査疼痛の軽減一どこまで無痛} に近づけるか?ー

\section{高木病院}

宮原 誠

【目的】男性における膀胱鏡検查は、軟性鏡を用いることによ り苦痛はかなり低減された。今回、麻酔時間の短縮かつ疼痛 軽減、検查への抵抗感の低減を目的として麻酔方法等のさら なる工夫を行ったので、その結果につき報告する。対象及び 方法】膀胱腫瘍等のため膀胱鏡検查（操作）を施行した男性 24 例。検査体位は仰臥位もしくは開脚位とし、尿道麻酔は $4 \%$ キシロカイン $4 \mathrm{ml}+2 \%$ キシロカインゼリー $6 \mathrm{ml}$ を混合 し、尿道に 30 秒以上かけて注入。約 2 分尿道圧迫後、軟性膀 胱鏡 (オリンパス製 CYF-4A, 15.6Fr) 扦入。検査後、疼痛 に対するアンケートを行った。疼痛の評価は (1) 麻酔薬注入 時、(2) 軟性鏡挿入時、(3) 観察捜査時の 3 時期に分け、visual analog scale (VAS) 方式 $(0-100 \mathrm{~mm})$ で患者自身が記載 した。また、採血、点滴、筋肉注射、胃カメラなどの他の処 置での疼痛に比較しての評価も尋ねた。結果】上記 3 時期に おける疼痛スケールの平均值 (mm) は（1）12.7、(2) 19.3、 （3）13.8であった。他の検査との比較では、採血より楽 $(28 \%)$ 、点滴より楽 $(50 \%)$ 、筋肉注射より楽 $(68 \%)$ 、胃力 メラより楽 $(92 \%)$ であった。検査後の気分不快、血尿、排 尿痛は全例に認めなかった。結論】この麻酔検査方法で、よ り非侵襲的に患者へ膀胱鏡を施行することができ、検査を勧 めやすくなった。さらなる改良を推進していきたい。

\section{PP3-054 若年性尿路上皮腫瘍の一例}

釧路労災病院泌尿器科1), 釧路労災病院病理科 21

堀田 記世彦 ${ }^{11}$, 石川 隆太 , $^{11}$, 丸山 覚 ${ }^{11}$, 菅野 貴行 ${ }^{11}$, 佐澤 陽1), 村雲 雅志"1), 小柳 知彦"1), 高橋 達郎2) 症例は 21 歳男性。平成 13 年 6 月 12 日無症候性肉眼的血 尿を生じ近医を受診。DIP で左腎孟の陰影欠損を指摘さ れ当科を紹介となった。既往としては一日 20 本の契煙と 20 才時 3 ケ月間叙装作業に従事したことがあった。左尿 管鏡で腎孟内に白い不整形の腫瘍を認めたが組織診では 確定しなかった。9ヶ月後再度血尿となり受診した。画像 上左腎孟の腫瘍に変化はなく、膀胱内に新たに左尿管口 周囲及び後壁に背の低い乳頭状腫瘍が確認された。経尿 道的膀腅腫瘍切除術を施行し、病理では UCC, G1, Ta で、 膀胱に関しては経過観察することにした。左腎㙉につい ては再度左尿管鏡を施行し、生検で UCC, G1 を得た。腫 瘍は腎孟のほぼ全体を占めており、腎温存は不可能と判 断し左腎尿管全摘術を施行した。病理は UCC. G1 = G2. pT1.pN0 だった。術後経過は良好で第 7 病日日に退院と なった。6 ケ月後現在再発なく経過中である。本例は多発 性尿路上皮腫瘍としては最年少例と思われる。

\section{PP3-055 当院における腎孟尿管癌症例の尿路再 発に関する検討}

\section{東部地域病院泌尿器科"), 東部地域病院検査科 ${ }^{2)}$}

横山 みなと ${ }^{1)}$, 有澤 千鶴 ${ }^{13}$, 安藤 正夫 ${ }^{1}$, 岡野 匡雄 ${ }^{2}$

【目的】当院における腎孟尿管癌の尿路再発について臨床 的に検討した。【対象】1990年の開設から 2003 年 9 月ま での間に当院において手術もしくは剖検により病理学的 に腎孟癌もしくは尿管癌と診断された 87 例を対象とし た。膀胱癌に対し膀胱全摘を施行した際に尿管浸潤が認 められた症例は含めなかった。結果】 87 例の内訳は男性 64 例、女性 23 例。年齢は 42 89 歳、平均 69.3 歳であっ た。腫瘍部位は右 37 例、左 45 例、両側 5 例、尿路内分 布は腎孟癌 26 例、尿管癌 52 例、腎孟尿管癌 9 例であっ た。このうち 83 例に対し手術が施行された。膀胱癌との 関係では膀胱癌の先行を 9 例、同時発見を 16 例、続発を 27 例に認めた。また、6 例に上部尿路再発を認めた。再 発回数は 0 から 9 回であった。 5 年生存率は尿路再発を 認めない症例では $69.4 \%$ 、尿路再発を認める症例では 79.4\%であった。両群間に有意差は認めなかった。考察】 腫湯の発生部位や、発見時の腫陽の個数あるいは組織型 が尿路再発に及ぼす明らかな傾向は認められなかった。 膀胱再発の部位に関しては少数回のうちは患側の尿管口 付近に発生しやすい傾向があるが、多数回になるにつれ そういった傾向は見られなくなった。また、上部尿路腫 瘟の尿路再発は生命予後には影響を与えなかった。

\section{PP3-056 腎孟尿管癌における予後因子の検討}

\footnotetext{
千葉大学泌尿器科 ${ }^{1)}$, 国保旭中央病院 ${ }^{2)}$

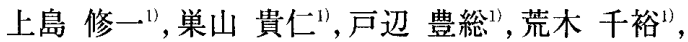
納谷 幸男 ${ }^{1)}$, 五十嵐 辰男 ${ }^{1)}$, 伊藤 晴夫 ${ }^{1)}$, 村上 信乃 ${ }^{21}$ 【目的】腎孟尿管癌における予後因子を臨床病理学的およ び免疫組織学的に検討した。方法】1975 年から 2000 年 までに千葉大学泌尿器科およびその関連施設である国保 旭中央病院泌尿器科において加療した腎盘尿管癌患者 271 例のうち、臨床病理学的に検討できた 69 例(男性 50 例、女性 19 例、平均年齢 65 歳）を対象とした。解析項 目として、病理学的パラメーターと、腫瘍増殖マーカー である ki67、癌抑制遺伝子の変化のマーカーである p53、 及び、組織浸潤マーカーであるMMP2、9につき検討し た。ki67、p53、MMP2、9については免疫組織染色を施行 し、染色細胞数によりラベリングインデックスを算定し て検討した。統計解析方法は、生存率の算定に KaplanMeier 法を使用した【結果・結論】病理学的パラメーター では、組織学的侵達度、組織学的異型度、微小リンパ管 侵襲、微小血管侵襲、リンパ節転移の有無は子後とよく 相関し、予後因子として有用であった $(\mathrm{p}<0.05)$ 。一方、 免疫組織染色では、ki67 のラベリングインデックスの み、予後因子として有用であった $(\mathrm{p}<0.05)$ が、 $\mathrm{p} 53 、 \mathrm{MMP}$ $2 、 9$ は、予後因子としての有用性が認められなかった。
} 